\title{
REFLECTIVE EQUILIBRIUM: EPISTEMOLOGICAL OR POLITICAL?
}

\section{Andrew Lister*}

One of the reasons for ongoing interest in the work of political philosopher John Rawls is that he developed novel methods for thinking systematically about the nature of justice. This paper examines the moral and epistemological motivations for Rawl's method of "reflective equilibrium," and the tension between them in Kai Nielsen's use of "wide reflective equilibrium" in the service of critical and emancipatory social theory.

Une des raisons de l'intérêt soutenu pour l'auvre du philosophe politique John Rawls est quil a développé de nouvelles méthodes de réflexion systématique au sujet de la nature de la justice. Cet article étudie les motifs moraux et épistémologiques soutenant la méthode d' "équilibre réflectif» de Rawls, et les tensions entre eux dans l'utilisation par Kai Nielsen d' "équilibre réflectif étendu" au service de la théorie sociale critique et émancipatrice.

Moral, social, and political philosophy should travel metaphysically and epistemologically light for both Rawlsian and Rortyian reasons; reasons which are different but do not conflict. ${ }^{1}$

\section{INTRODUCTION}

One of the reasons for ongoing interest in the work of John Rawls is the systematic nature of his thought. Rawls developed a conception of justice that involved an ordered set of principles (equal basic liberties, fair value of political liberties, fair equality of opportunity, social and economic inequalities only if they raise the lowest social position). He did so by asking what principles rational parties could all agree to, if they were situated in fair initial conditions. And, this contractualist thought experiment was located in a more general, coherentist approach to justification, known as reflective equilibrium. After developing principles of justice, we must flesh out their institutional consequences. If these implications clash with our considered judgments about the justice of specific policies and procedures, then we must either revise these judgments to accord with our principles or go back and modify our account of the initial choice situation. For it may be that we made some mistake in articulating the idea of fair conditions for reaching an agreement. If we left anything out, or included some conditions we should not have, re-specifying the terms of the thought experiment may yield principles more in line with our judgments about justice in particular cases; if

* Department of Political Studies, Queen's University. The first draft of this paper was written at the Centre de recherche en éthique de l'Université de Montréal (CREUM), where I was a postdoctoral fellow, courtesy of the Fonds québécois de la recherche sur la société et la culture (FQRSC). I would like to thank Kai Nielson for his detailed comments on the paper.

1 Kai Nielsen, "How to Proceed in Social Philosophy: Contextualist Justice and Wide Reflective Equilibrium" (1994) 20 Queen's L.J. 127 [Nielsen, "How to Proceed in Social Philosophy"].

(2008) 26 Windsor Y.B. Access Just. 
not, we will have to abandon the judgments in question. By iterating this process of revising the initial choice situation and revising our considered judgments, we may ultimately arrive at a coherent and fully articulate account of justice, or, in other words, a reflective equilibrium. The contractualist and coherentist elements of Rawls's method were thus intended to work together, the «original position» serving to avoid the unprincipled achievement of coherence that could otherwise be obtained by arbitrarily adjusting principles and judgments.

In subsequent debate, Rawls's contractualism has fared less well than his coherentism. Many would accept Will Kymlicka's view that the original position is merely one possible heuristic device for drawing out the implications of a more fundamental ideal of equality or impartiality. ${ }^{2}$ In contrast, the idea of reflective equilibrium has been widely adopted, or at least widely recognized as what political theorists in fact do. ${ }^{3}$ Less well recognized is that the idea of reflective equilibrium has two rather different and possibly conflicting motivations. This conflict can be brought out by noticing the difference between reflective equilibrium as a goal and reflective equilibration as an activity. It is hardly controversial to say that it is appropriate for people to identify and remove inconsistencies between the general principles they espouse and the judgments they are inclined to make about specific laws and policies. What is controversial is to suggest that this reconciliation of principles and judgments should aim at coherence (equilibrium) rather than truth. One reason for aiming at coherence rather than truth would be that principles of justice cannot correspond to or be grounded in an independent moral reality. A quite different reason would be that, whether or not such foundations exist, we need to reach agreement on standards for assessing institutions, and in particular our highest standards, which are our principles of justice in Rawls's terminology. We need to reach agreement despite the inevitability of reasonable disagreement about religion, philosophy, and ethics, including disagreement about foundationalism. The purpose of this paper is to explore the tension between these two motives for reflective equilibrium, one epistemological and the other political, to adapt Rawls's phrase. ${ }^{4}$

The Canadian philosopher Kai Nielsen has done more than anyone to promote reflective equilibrium as a method for normative thinking. One of Nielsen's central concerns has been to explain, defend, and apply this method, as part of his vision of philosophy as critical theory. Nielsen is aware that two kinds of considerations motivate the development of this nonfoundationalist method of justification: a Rortyian denial of the existence of philosophical foundations, and a Rawlsian attempt to avoid appeals to controversial religious, metaphysical, or philosophical ideas. In the opening quote, Nielsen claims that these two motivations do not conflict. However, the Rortyian reason for not making foundationalist claims is that they are indefensible, whereas the Rawlsian reason is

2 Contemporary Political Philosophy: An Introduction (Oxford: Clarendon Press, 1990) at 67-69.

3 Wayne Norman, "Inevitable and Unacceptable? Methodological Rawlsianism in Anglo-American Political Philosophy" (1998) 46:2 Political Studies 276 at 294.

4 John Rawls, "Justice as Fairness: Political Not Metaphysical" in Samuel Richard Freeman, ed., Collected Papers (Cambridge, Mass.: Harvard University Press, 1999) 388 [Rawls, "Justice as Fairness: Political Not Metaphysical"]. 
that they will inevitably be a matter of deep, reasonable controversy, and hence inappropriate as justifications for the design of social institutions. As Mathias Fritsch argues, Nielsen's insistence that a truly wide reflective equilibrium include a broad range of psychological, sociological, political, biological, and even cosmological theories seems to conflict with Rawls's insistence that a political conception of justice be as independent as possible of controversial doctrines. ${ }^{5}$

This paper describes the origin in Rawls's writings of the epistemological and political motivations for reflective equilibrium, sets out the conflict that emerges between them in Nielsen's work, and considers how we might avoid the conflict. Using the example of disputes over policies relating to sexual orientation, I suggest that the conflict cannot be avoided. The very wide kind of reflective equilibrium one would want to invoke in service of a critical theory aiming at emancipation is fundamentally at odds with the narrower kind of reflective equilibrium that supports a political conception of justice.

\section{RAWLS ON REFLECTIVE EQUILIBRIUM}

Rawls's initial presentation of his coherentist method in 1951's "Outline of a Decision Procedure for Ethics" was motivated in part by epistemological concerns. Rawls argued that the objectivity of moral knowledge did not depend on the existence of ideal value entities, but on the existence of a reasonable method for validating proposed rules of conduct, in cases where interests conflict. ${ }^{6}$ The discipline of ethics was analogous to that of inductive logic, he claimed. ${ }^{7}$ Rules of induction cannot be true, in the ordinary sense of corresponding to reality, since these rules do not describe the world but prescribe patterns of thought. Similarly, rules prescribing modes of interpersonal conduct cannot be true in the ordinary sense, but can have a form of objectivity. Rawls expanded on this epistemological rationale in A Theory of Justice [Theory], adding a comparison of ethics to grammar, and referring to the work of Nelson Goodman, Noam Chomsky, and W. V. Quine. Rawls suggested that the attempt to describe our sense of justice was similar to the attempt to describe our capacities for speech and inductive reasoning. ${ }^{8}$ In all three cases we are concerned with making explicit the rules that (to some extent) govern forms of conduct, and then trying to refine, adjust, and extend these rules to problematic cases. ${ }^{9}$ Rawls's reference to Quine suggested a more general kind of antifoundationalist rationale for reflective equilibrium, though Rawls did not pursue this line of thought. ${ }^{10}$ According to the epistemological motivation, then, reflective equilibrium solves the problem of

5 Mathias Fritsch, "Wide Reflective Equilibrium and Critical Social Theory" in Michel Seymour \& Matthias Fritsch, eds., Reason and Emancipation: Essays on the Philosophy of Kai Nielsen (Amherst, N.Y.: Humanity Books, 2007) 95 at 99-100.

6 John Rawls, "Outline of a Decision Procedure for Ethics" in Freeman, supra note 4, 1 at 1 [Rawls, "Outline"].

7 Ibid. at 12, 16, 18.

8 John Rawls, A Theory of Justice (Cambridge, Mass.: Harvard University Press, 1971) at 46-47 [Rawls, Theory of Justice].

9 Ibid. at 48-49.

$10 \mathrm{Ibid}$. at 579 , n. 33. 
how it is possible to reason about ethics at all, given the meta-ethical view that truth-as-correspondence is out of the question, for moral principles. Reflective equilibrium's special kind of coherentism would show how moral statements could have objective validity, contrary to the subjectivism of contemporary positivists, without claiming that they correspond to an independent moral reality, or can be deduced from self-evident first principles.

Even in Rawls's early work, however, there were elements of a non-epistemological rationale for reflective equilibrium. The decision procedure Rawls set out in 1951 was based on existing consensus and aimed for expanded consensus. Rawls began with criteria of "competence" in moral judging and "consideredness" in moral judgments, criteria he claimed were widely accepted independent of the specific moral principles to which people subscribed. Reasonable principles had to explicate the considered judgments of competent judges, but also yield results that come to be accepted by them. ${ }^{11}$ The idea was to start with agreement on some matters, then clarify, refine, and extend this consensus to resolve disagreement on other matters. Though the agreement of competent judges after reflection and discussion would suggest correctness, reconciliation was important in its own right. ${ }^{12}$ Rawls developed this theme in his discussion of justification in Theory. In response to the objection that the method of reflective equilibrium appealed to mere agreement, and so did not justify its conclusions, Rawls claimed that "justification is argument addressed to those who disagree with us." Justification presumes a clash of views and seeks to convince those involved in the disagreement by starting from "what all parties to the discussion hold in common." 13 This conception of justification suggests that reflective equilibrium is not so much a set of rules for discovering or demonstrating ethical truths, as it is a social activity aimed at reconciling the parties involved in a conflict - forging a common point of view.

Rawls was aware that there might not be only one equilibrium that all competent moral reasoners would reach, particularly if the notion of a «reflective» equilibrium was interpreted narrowly. ${ }^{14}$ In the narrow sense, one reaches reflective equilibrium when one has managed to reconcile one's specific judgments with whatever general principles one happens to be aware of. Achieving this kind of reflective equilibrium leaves one's sense of justice more or less where it is, except for «smoothing out of certain irregularities.» Therefore, if people start with quite different judgments, they may remain far apart, each in their own local equilibrium. In contrast, one reaches a wide reflective equilibrium by considering a range of possible principles from the philosophical tradition, along with their supporting arguments. Each competing set of principles represents a possible description of one's sense of justice. Looking for coherence between one's list of judgments and these different abstract descriptions may lead to significant changes in belief, Rawls claimed - and hence, to rapprochement with

11 Rawls, "Outline", supra note 6 at 10-11.

12 On the importance of reconciliation in Rawls's thinking, see Daniel M. Weinstock, "The Justification of Political Liberalism” (1994) 75:3 Pacific Philosophical Quarterly at 166.

13 Rawls, Theory of Justice, supra note 8 at 580-581.

14 Ibid. at 49-50. 
the views of others. Widely reflective equilibrium has the possibility of moving people out of their various local equilibria into a common equilibria. In moral philosophy, Rawls said, we are clearly concerned with the widely reflective kind of equilibrium. ${ }^{15}$ On the one hand, only wide reflective equilibrium will seem an adequate substitute for the unattainable truth-as-correspondence. On the other hand, only wide reflective equilibrium can lead to convergence of views, if people are initially far apart.

It is important to recognize that the width of Rawls's wide reflective equilibrium consisted in considering a range of possible descriptions of one's sense of justice - a range of candidate principles and supporting arguments. It is conceivable to widen the notion of reflection in other ways. For example, our considered moral judgments about specific laws and policies may presuppose or imply empirical claims of various sorts, even claims about the existence or non-existence of God. An even wider form of reflective equilibrium would require that we test or screen our judgments for their compatibility with the best scientific theories, even perhaps with naturalism or atheism. As we will see, this widening of the notion of reflection will drive a wedge between the goals of truth and reconciliation.

The distinction between the epistemological and political motivations for reflective equilibrium became clearer post-Theory. In "The Independence of Moral Theory," Rawls suggested bracketing the problem of moral truth in order to focus on the task of describing substantive moral conceptions by using the method of reflective equilibrium. ${ }^{16}$ Rawls claimed that reflective equilibrium did not rule out the possibility that moral conceptions could be based on selfevident first principles. All he would say is that «it is natural to suppose» that agreement between moral conceptions in reflective equilibrium is a necessary condition for objective moral truth. ${ }^{17}$ Rawls did not expect full convergence of views even if everyone attained wide reflective equilibrium. The possible outcomes, given universal attainment of wide reflective equilibrium, were that one conception wins out over the rest, that everyone still affirms opposing conceptions, or that a small number of conceptions persist. In the latter, intermediate case, the conceptions could be related to one another in different ways. On the one hand, each might conflict with the other, allowing no basis for agreement, but on the other hand, «they may have some significant principles in common," which would define «absolute» morality on analogy with «absolute geometry.» In this latter and «most probable» case, Rawls said, «one would like to know the consequences of the principles of absolute morality and whether these principles are rich enough to afford a constructive basis of mutual accommodation.» ${ }^{18}$

In "Justice As Fairness: Political Not Metaphysical," Rawls made explicit the

15 Ibid. at 49.

16 John Rawls, "Independence of Moral Theory" in Freeman, supra note 4, 286 at 288 [Rawls, "Independence of Moral Theory"].

17 Ibid. at 289-290; See T. M. Scanlon, "Rawls on Justification" in Samuel Richard Freeman, ed., The Cambridge Companion to Rawls (Cambridge: Cambridge University Press, 2003) at 151.

18 Rawls, "The Independence of Moral Theory", supra note 16 at 290. In this passage, Rawls is clearly using the term "absolute" in a technical sense, which could be quite misleading, taken out of context. 
disconnect between political and epistemological considerations. The problem political philosophy confronted was the lack of a publicly recognized basis for a conception of justice. ${ }^{19} \mathrm{~A}$ democratic society would always be home to a diversity of religious, philosophical, and moral conceptions, because the free exercise of human reason does not generate convergence of opinion on many important questions in these domains. How then might we find a shared basis for settling the question of the appropriate institutionalization of liberty and equality? Rawls' answer was reflective equilibrium; start with settled convictions such as religious toleration and the rejection of slavery, and try to organize the basic ideas implicit in these convictions into a coherent conception of justice, without taking a position on the possibility of moral truth, the controversy between realism and subjectivism, or other such questions. ${ }^{20}$

According to this second motivation, which I am calling 'political,' reflective equilibrium solves the problem of disagreement, not the problem of truth. From this perspective, reflective equilibrium is not a response to any meta-ethical view about the metaphysical status of moral values. It is rather part of a democratic political theory. Reflective equilibrium shows how we can reason together about collective institutions and policies in a way that makes it possible, in principle, for us to come to some common political understanding, despite the inevitability, in a modern democracy, of deep reasonable disagreement about many religious, philosophical, and moral questions. Rather than denying the existence of moral foundations, we should recognize the inevitability of disagreement about such matters, and seek to find reasonably acceptable terms of political cooperation, i.e. terms justified on grounds that all reasonable persons could come to share, without having to give up the religious and philosophical doctrines they not unreasonably espouse. This process of policy-justification against the background of religious and philosophical disagreement will necessarily have a coherentist character, but need not be motivated by an antifoundational moral epistemology, and could even be thwarted by appealing to such a theory.

It might seem that reflective equilibrium is merely a rhetorical strategy useful for achieving one's political objectives, whatever they may be, or for resolving conflict peacefully. Yet, there is reason to think that for Rawls the method of reflective equilibrium was more intimately connected with his substantive ideas about justice and legitimacy. As Charles Larmore argues, the idea of public reason has always been at the heart of Rawls's philosophy, not just as one political value among others, but as the encompassing ideal that governs our relationship to each other as citizens. In Larmore's formulation, we honour public reason when we seek a common point of view for settling the terms of our political life, endorsing a conception of justice for reasons that all can share, where the fact that all can share these reasons is essential to our endorsing them. ${ }^{21}$ This idea of public reason was implicit in Rawls's 1958 discussion of "the possibility of mutual acknowledgment of principles" as a condition for "true community."

19 Rawls, "Justice as Fairness: Political Not Metaphysical", supra note 4 at 390.

20 Ibid. at 393-395.

21 Charles Larmore, "Public Reason" in Freeman, supra note 17, 368; see also Scanlon, "Rawls on Justification”, supra note 17 at 160-161. 
"Persons engaged in a just, or fair, practice, can face one another openly and support their respective positions ... by reference to principles which it is reasonable to expect each to accept." ${ }^{22}$ In Theory, the same idea reappeared in Rawls's conception of a society well-ordered by a public conception of justice. Conflict would still arise in such a society, but people would have a common point of view from which their claims might be adjudicated, thus establishing "the bonds of civic friendship." ${ }^{23}$ Rawls's "method of avoidance" ${ }^{24}$ was rooted in this requirement that a conception of justice represent a kind of common understanding or general will, given the fact of reasonable pluralism.

The contractarian element of Rawls's method can also be seen as a response to the fact of reasonable pluralism, although Rawls did not originally use this term. Given the inevitability of reasonable religious, philosophical, and ethical disagreement, how are we to decide upon fair terms of cooperation? If our principles of justice could only be deduced from one particular «comprehensive doctrine,» not all citizens would be able to freely and willingly endorse the social order. A sensible way to proceed, then, would be to ask what principles everyone could agree to, if they didn't know what doctrine they subscribed to, but were committed to protecting their status as free and equal citizens and the capacities necessary to this status. Agreement behind a veil of ignorance secures two kinds of impartiality in the choice of principles: between my good and yours, and between our competing conceptions of the general good that we hoped social institutions would promote. ${ }^{25}$

\section{NIELSEN ON WIDE REFLECTIVE EQUILIBRIUM}

Both the epistemological and the political motivations for wide reflective equilibrium are present in Nielsen's writings, though the epistemological reasons dominate, and his political motivation for wide reflective equilibrium is somewhat different than Rawls's. After defending Rorty's antifoundationalism in the first part of After the Decline of the Tradition, Nielsen devoted much of the second part of the book to developing wide reflective equilibrium as the appropriate method for a pragmatic, critical philosophy that has human emancipation as its goal. At this stage, at least, Nielsen's conception of wide reflective equilibrium was motivated by an antifoundationalist epistemology, as well as by the goal of radically transforming an unjust and inhumane world. ${ }^{26}$

22 John Rawls, "Justice as Fairness" in Freeman, supra note 4, 59; see Larmore, ibid. at 374.

23 Rawls, Theory of Justice, supra note 8 at 5.

24 Rawls, "Justice as Fairness: Political Not Metaphysical", supra note 4 at 395.

25 The distinction between ordinary impartiality and "higher-order" impartiality is from Thomas Nagel: Thomas Nagel, "Moral Conflict and Political Legitimacy" (1987) 16 Philosophy and Public Affairs 215 at 215-216.

26 True, many of Nielsen's formulations simply describe wide reflective equilibrium as not involving foundationalist claims; Kai Nielsen, After the Decline of the Tradition: Rorty, Critical Theory, and the Fate of Philosophy (Boulder, Co.: Westview Press, 1991) at 205-206, 231 [Nielsen, After the Decline of the Tradition]; Kai Nielsen, "Relativism and Wide Reflective Equilibrium" (1993) 76:3 The Monist 316 at 318 [Nielsen, "Relativism and Wide Reflective Equilibrium"]. At other times, however, he describes wide reflective equilibrium as a frankly antifoundational moral theory, making it clear that the reason for not making foundationalist claims is that they cannot be 
Yet, After the Decline of the Tradition also contains elements of a political conception of wide reflective equilibrium. Nielsen argued that wide reflective equilibrium remained "utterly neutral" on the meta-ethical issue of the nature and possibility of moral truth. If successful, wide reflective equilibrium "would provide an account of how moral beliefs can be justified without taking sides on arcane epistemological and semantical issues." 27 Nielsen also claimed that in seeking wide reflective equilibrium we begin from common convictions embedded in our normative traditions, not just the considered judgments of a particular person. ${ }^{28}$ The strategy of wide reflective equilibrium is "to work outward from a consensus - what predictably will be a widening consensus - toward the contested areas." 29 The aim of wide reflective equilibrium is not just truth (perhaps solitary truth) but consensus; 30 "the equilibrium we seek is clearly a social equilibrium," Nielsen says. ${ }^{31}$ The importance of consensus is related to Nielsen's pragmatism - his vision of critical theory as "a method for coming to grips with determinate problems of human beings that could be utilized in social disputes." 32 Although solving problems may initially mean identifying injustice heretofore unrecognized, and hence stirring up disagreement, solving recognized problems requires resolving these disputes, in the sense of (eventually) reconciling the opposing parties.

The distinction between the two motivations for wide reflective equilibrium became clearer in Nielsen's 1994 article "How to Proceed in Social Philosophy," from which the opening quote is taken. Nielsen now presented wide reflective equilibrium as a non-foundational, but not necessarily anti-foundational, method. ${ }^{33}$ Yet at times, he still ventured ambitious epistemological claims much more Rortyian than Rawlsian in flavour. For example, Nielsen rejected the idea that in achieving wide reflective equilibrium we might also be discovering "some underlying structure revealing what the truth about morality really is." He rejected,

vindicated. For example, Nielsen opens the chapter entitled "In Defense of Wide Reflective Equilibrium" by saying that traditional moral philosophy is based on a mistake. "[A]ccounts such as the various varieties of utilitarianism, deontology, contractarianism, rights-based theories or perfectionism cannot attain the kind of justificatory purchase they seek and need .... Moral philosophy needs to redefine its role. A start is to develop in the understanding of moral domains as thorough an antifoundationalism and coherentism as Quine, Davidson, and Rorty have developed in what was once called epistemology." Nielsen, After the Decline of the Tradition at 231. Nielsen makes similar claims in the opening pages of in "Relativism and Wide Reflective Equilibrium." "Wide reflective equilibrium is a holistic anti-foundationalist account of morality. There is, on such an account, no conception of basic or fundamental moral beliefs or principles which will provide an unchallengeable basis for moral belief. Wide reflective equilibrium sets aside any such quest for certainty .... For wide reflective equilibrium, there can be no such ahistorical, perfectly general, Archimedean point. Indeed the very idea of seeking an Archimedean point will be seen to be a mistake" Nielsen, After the Decline of the Tradition at 317. Also see at 205, 215, and 232 for other antifoundationalist statements, and also Nielsen, "How to Proceed in Social Philosophy", supra note 1 at 91-92, 116-117.

27 Nielsen, After the Decline of the Tradition, ibid. at 237, 239.

28 Ibid. at 201; Nielsen, "Relativism and Wide Reflective Equilibrium", supra note 26 at 317.

29 Nielsen, After the Decline of the Tradition, supra note 26 at 216.

$30 \mathrm{Ibid}$. at 225.

31 Nielsen, "Relativism and Wide Reflective Equilibrium", supra note 26 at 317.

32 Nielsen, After the Decline of the Tradition, supra note 26 at 225.

33 Nielsen, "How to Proceed in Social Philosophy", supra note 1 at 89-91, 93, 106. 
even as a heuristic ideal, the idea that a wide enough reflective equilibrium will finally yield the one true morality. "That is no more possible, or perhaps even intelligible, than is the idea of there being a uniquely true description of the world: a one true description of the world." ${ }^{34}$ The claim to have found the one true morality would of course be highly ambitious, but the claim that such a morality could never be found is also ambitious - the kind of claim that will inevitably be a matter of controversy in a democratic society, given the tendency of reasonable people to disagree about such matters.

What makes the tension between the epistemological and political motivations for wide reflective equilibrium a real conflict, in Nielsen's case, is his Marxian hope for human emancipation - not just justice, but liberation from at least some of the conditions making principles of justice necessary. ${ }^{35}$ The aim of Nielsen's critical theory is to show us "what kind of society would be not merely a more just society but also a more humane society that more adequately meets human needs and aspirations." ${ }^{66}$ The "emancipatory thrust" of this theory is that it gives us "an adequate account of what a good society, what a truly human society, given historically feasible possibilities, would look like." ${ }^{\prime 7}$ Nielsen's vision of a society that is not only just but humane is inspired by Marx's conception of a society beyond justice, though Nielsen is much less certain than was Marx about the extent to which such a society could be realized. As Nielsen explains, the classless societies Marxists hope for "are supposed to be truly human societies where social relations, including face-to-face relations, will generally become clear. We will, at last, understand the truth about our world and about ourselves and finally we will have a just society, or perhaps even a society 'beyond justice,' of equals." ${ }^{38}$ Liberation or emancipation, in this sense, would consist not just in the end of injustice (e.g. barriers to equal citizenship) but in freedom from many of the conditions that ordinarily make formal rules, rights, duties, and procedures necessary to social life (conditions such as selfishness and disagreement). True, Nielsen admits that in a socialist society, "if anything like this could come to be," the problems of physical decline in old age, death, and personal conflict would remain, with the result that the end of class conflict would not automatically lead to the disappearance of religion, as Marx and his followers expected. ${ }^{39}$ Nonetheless, Nielsen holds out the prospect that, in a classless society, our responses to the problems of death and personal conflict might increasingly take a secular form. ${ }^{40}$ If, globally, we eventually came to have security, material well-being, education, leisure, and some measure of equality, religion might wither, as the existential functions of religion are increasingly fulfilled by secular cultural practices. ${ }^{41}$

34 Ibid. at 121 .

35 Steven Lukes, Marxism and Morality (Oxford: Clarendon Press, 1985) at 27-30.

36 Nielsen, After the Decline of the Tradition, supra note 26 at 211.

37 Ibid. See also Nielsen's comments at 209-211 about human enhancement, self-development, and liberation of human powers, which suggest a comprehensive vision of human flourishing, rather than a narrower Rawlsian focus on justice between free and equal citizens.

38 Naturalism Without Foundations (New York: Prometheus Books, 1996) at 484.

39 Ibid.

$40 \mathrm{Ibid}$. at 485.

41 Ibid. at 499. 
If the pursuit of reflective equilibrium is to further this chastened but still emancipatory vision, the equilibrium sought must be a very wide reflective equilibrium, as Nielsen recognizes. ${ }^{42}$ Rawls's account of the distinction between wide and narrow reflective equilibrium remained basically the same over the years. To be widely reflective, an equilibrium had to be reached after consideration of other conceptions (of justice) and the various arguments for them. ${ }^{43}$ Norman Daniels made the point that our views about justice rest on what he called "background theories," including general social and psychological theories relevant to testing the feasibility of alternate conceptions. ${ }^{44}$ The idea here is not to consider different theories as we considered different possible principles, but to use the best supported theories to screen out judgments that rest on or imply faulty empirical claims. Rawls insisted that proper political arguments for principles of justice should appeal only to scientific claims that are uncontroversial, in the sense of being very widely accepted among reasonable persons. ${ }^{45}$ According to Nielsen, however, Rawls's accounts of wide reflective equilibrium remain "too traditional." ${ }^{46}$ A narrow reflective equilibrium involving only a set of considered judgments and a cluster of moral principles would not yield a critical morality, in Nielsen's view, since even highly ideological, prejudiced, or superstitious beliefs may be systematized. Such convictions ought not to count as truly considered judgments, but weeding them out may require that we tease out the empirical presuppositions and implications of these judgments, and compare them to the best available natural and social scientific evidence. According to Nielsen, the pursuit of wide reflective equilibrium brings in these kinds of background theories. Our judgments are revisable in light of their fit with other judgments and principles, but they need to be screened for consistency with the best sociological, political, psychological, cognitive, biological, and even cosmological theories. Within the domain of "background theories," Nielsen includes "what we know about the world, the best available human sciences and social theories, the best account of the role of morality in society, and our best natural science knowledge, including the cosmological claims that in that circumstance could most reasonably be made. (The latter are important where religious issues are likely to enter our moral deliberations.) ${ }^{\prime 47}$ The problem, from the perspective of

42 Ibid. at 205.

43 Rawls, Theory of Justice, supra note 8 at 49; Rawls, "Independence of Moral Theory", supra note 16 at 289; John Rawls, Political Liberalism (New York: Columbia University Press, 1996) at 384, n. 16 [Rawls, Political Liberalism].

44 Justice and Justification: Reflective Equilibrium in Theory and Practice (New York: Cambridge University Press, 1996) at 22-23.

45 Rawls, Political Liberalism, supra note 43 at 224-225.

46 After the Decline of the Tradition, supra note 26 at 208-209.

$47 \mathrm{Ibid}$. at 224. This is Nielsen's most ambitious, inclusive formulation of the range of 'background theories' figuring in wide reflective equilibrium; see at 200, 203, 207, 208, 219 for other formulations. Nielsen later explains that "among our moral beliefs some are surely likely to be little better than superstitions. Others become effectively 'ours' through domination, manipulation, or because we have cosmological conceptions that are not only outmoded by without rational warrant .... We should be wary indeed of getting these beliefs into some reflective equilibrium, and in seeking equilibria, we should also beware of too quick a closure," at 229. It seems clear that in this passage, what Nielsen means by 'best' scientific theories is the truly most plausible theories, 
the political rationale for wide reflective equilibrium, is that there will tend to be deep, intractable, but not unreasonable disagreement on at least some of the theories Nielsen claims are essential to make wide reflective equilibrium a truly critical method. ${ }^{48}$

\section{CRITICAL THEORY VS. POLITICAL LIBERALISM}

Even if the epistemological and political motivations for wide reflective equilibrium conflict, perhaps we can deploy different forms of reflective equilibrium in different contexts, for different purposes. As Nielsen says in response to Fritsch, «[w]ide reflective equilibrium can be used for many purposes, and some elements of it change with the purpose it is used for ..... ${ }^{49}$ For example, Rawls argues that the ideal of public reason constrains discussion that is part of a political decision-making procedure, but not discussion in what he calls the «background culture» of civil society, because in ordinary debate the exercise of political power is not at stake. ${ }^{50}$ In ordinary public debate one could therefore deploy a Rortyian version of wide reflective equilibrium, whereas when engaging in political advocacy, one would deploy the narrower, Rawlsian version of wide reflective equilibrium. In the recent debates about same-sex marriage, for example, many people have claimed that marriage is an institution defined by God, which the state cannot redefine as it pleases. ${ }^{51}$ Atheist naturalists may be

relative to other competing theories, rather than, in a more Rawlsian vein, only those theories so highly plausible as to be very generally accepted; Rawls, Political Liberalism, supra note 43 at 224. The most plausible view might be that there is no God, at least no God that fits the description of standard theism. Nonetheless, the claim that there is no God is deeply controversial among people who would otherwise count as reasonable, unlike the claim that evolution occurred, which is not controversial in this sense.

48 Of course, endorsing the political conception of wide reflective equilibrium would not mean that we must always shy away from controversy. The idea of a political conception of justice is not that of a balance-of-power truce between warring factions motivated by strategic considerations, nor even that of a compromise for the sake of social peace. Where there is disagreement over issues of law and policy touching on essential guarantees of civil liberty and equality, political liberals will not necessarily want to avoid controversy; Larmore, "Public Reason" in Freeman, supra note 21 at 384. However, in formulating fundamental principles of liberty and equality, political liberals will want to appeal only to background theories capable of being endorsed by all reasonable persons, whatever the comprehensive doctrine they reasonably espouse. Atheist naturalism (for example) would not meet this requirement.

49 "Reply to Matthias Fritsch" in Seymour \& Fritsch, supra note 5, 111 at 120.

50 Political Liberalism, supra note 43 at 214; Stephen Macedo, "In Defense of Liberal Public Reason: Are Slavery and Abortion Hard Cases?" (1997) 42 Am. J. Juris. 11 at 21; Larmore, "Public Reason" in Freeman, supra note 21 at 383; Martha Craven Nussbaum, "Rawls and Feminism" in Freeman, supra note 17 at 495, 507-08.

51 This view was asserted repeatedly in the 2003 hearings on same-sex marriage held by the Canadian Parliament's Standing Committee on Justice and Human Rights. See e.g. the comments by André Gaumond of the Canadian Conference of Catholic Bishops, and by Franklin Pyles of the Evangelical Fellowship of Canada, both from the $13^{\text {th }}$ of February hearing, the transcript of which is available at online: House of Commons Committees $<$ http://cmte.parl. $\mathrm{gc} . \mathrm{ca} / \mathrm{cm}$ te/CommitteePublication. aspx?SOurceId=22780\&Lang=1\&PARLSES=372\&JNT=0\& $\mathrm{COM}=3297>$. Daniel Cere, Director, Newman Insititute of Catholic Studies, McGill University, Montreal, made the same point in his submission to the Ontario same-sex marriage court case 
tempted to roll out the apparatus of wide reflective equilibrium and argue that there is no God, and hence no natural purpose for marriage. This is what they would do in a debate on the existence of God on campus, say, or in the religion section of the Sunday paper. Yet in the context of a decision about policy, Nielsen could take a less confrontational line, based on a narrower form of reflective equilibrium. He might even assert that religious and other «comprehensive» doctrines should not be considered relevant to decisions about public institutions and policies, in a pluralistic democracy.

For a political liberal, however, philosophical avoidance is not just a rhetorical strategy but a moral constraint on the design of (basic) social institutions and policies. The intuition is that, because (a) membership in a political society is not (fully) voluntary, (b) the design of basic institutions has a large effect on people's desires and aspirations, and (c) political decisions are backed ultimately with collective authority and the legitimate use of force, we ought not to design social institutions and policies according to ideals and doctrines that will inevitably be a matter of deep controversy even between reasonable persons. ${ }^{52}$ If he were to limit the application of wide reflective equilibrium to the so-called «background culture,» Nielsen's critical, pragmatic philosophy would become a private philosophy like any other, capable of changing hearts and minds, perhaps, but not permitted to influence the development of public policy or the design of social institutions.

One might claim that whether one brackets the religious and philosophical questions at stake in same-sex marriage or answers them according to Nielsen's atheist naturalism, the outcome is still support for same-sex marriage. In this case, the Rawlsian constraint on Nielsen's emancipatory critical theory would not be binding, i.e. it would be without cost. Consider the following questions, however:

- Should private schools (or parents) be allowed to teach their children that homosexuality is sinful?

- Should churches claiming that homosexuality is sinful be eligible for charitable tax status?

(cited in Halpern v. Canada, online: Metropolitan Community Church of Toronto < http://www. mcctoronto.com/Documents/marriage_ruling.pdf>). See also Lorna Dueck, "Can This Marriage be Saved? The Sacred Definitions God Hath Wrought, the Supreme Court May Break Asunder - But Not if We Can Stop It" The Globe and Mail (6 October 2004), A 23.

52 Nielsen denies that there is any plausible reason for believing in standard theism. He might therefore accept the Rawlsian constraint of reasonable acceptability, while drawing the boundaries of the reasonable more narrowly than does Rawls. But even if one cannot be fully reasonable while believing in standard theism, many intelligent and well-intentioned people - people willing and able to reason honestly about the issues, people with reasonable beliefs about other issues - remain committed to Christianity, Judaism, Islam, and other standardly-theistic religions, as Nielsen recognizes. We cannot therefore say that these people are unreasonable, particularly if, in addition to being otherwise epistemically reasonable, they are practically reasonable, in the sense of wanting to live according to fair terms of cooperation and taking into account the inevitability of reasonable disagreement in a democratic society. Whether one rejects the Rawlsian principle of toleration or classifies theists as unreasonable for purposes of applying this principle, one has abandoned the distinctive Rawlsian vision of justice and public reason. 
- Should private schools or churches be permitted to discriminate in hiring based on sexual orientation, or based on the person's beliefs about the ethical status of sexual orientation?

- Should religious condemnation of homosexuality be considered hate speech? ${ }^{53}$

On such questions, it will, I think, make a difference whether one believes public decisions should bracket the question of sin and sexual orientation or take the stance that neither homosexuality nor heterosexuality is sinful, i.e. that the two are fully ethically and spiritually equivalent. On the former view, our policy would be that as citizens acting collectively via the state, we would aim to remain neutral between a number of different views about the morality of sexual orientation. ${ }^{54}$ On the latter view, our policy would be to take a public stance that the Catholic Church and other conservative religious groups are wrong about the sinfulness of homosexual conduct. If emancipation is our goal, and a very wide reflective equilibrium our critical standard, we ought to adopt the latter view, limited only by strategic considerations, given the numbers and the forces involved in specific political contexts. My question is whether the state should set itself against conservative religious groups in this comprehensive. I tend to think not, but Nielsen's critical theory seems to pull us in this direction. No doubt there are ways he could resist this pull, but I am unsure whether he would want to.

53 For simplicity, I have framed these issues as yes or no questions, but of course in each case there is a range of possible answers.

54 Neutrality extends across 'a number' of doctrines rather than across all possible views, since a policy of equal rights for all regardless of sexual orientation will necessarily conflict with some religious doctrines, e.g. those claiming that homosexuality is such a serious sin that it should be a crime. 